\title{
Influence of Temperature on the Ratio of Ribulose Bisphosphate Carboxylase to Oxygenase Activities and on the Ratio of Photosynthesis to Photorespiration of Leaves
}

\author{
B. LEHNHERR, F. MÄCHLER AND J. NÖSBERGER
}

Institut für Pflanzenbau, Eidgenössische Technische Hochschule, Universitätstrasse 2, CH-8092 Zürich, Switzerland

Received 16 October 1984

\begin{abstract}
A BSTRACT
Lehnherr, B., Mächler, F. and Nösberger, J. 1985. Influence of temperature on the ratio of ribulose bisphosphate carboxylase to oxygenase activities and on the ratio of photosynthesis to photorespiration of leaves.-J. exp. Bot. 36: 1117-1125.

Rates of net and gross photosynthesis of intact white clover leaves were measured by infrared gas analysis and by short term uptake of ${ }^{14} \mathrm{CO}_{2}$ respectively. Ribulose bisphosphate carboxylase oxygenase (RuBPCO) was purified from young leaves and kinetic properties investigated in combined and separate assays. The ratio of carboxylase to oxygenase activities was compared with the ratio of photosynthesis to photorespiration at various temperatures and $\mathrm{CO}_{2}$ concentrations.

The ratio of photosynthesis to photorespiration at $30 \mathrm{~Pa} p\left(\mathrm{CO}_{2}\right)$ was consistent with the ratio of carboxylase activity to oxygenase activity when each was measured above $20^{\circ} \mathrm{C}$. However, the ratio of photosynthesis to photorespiration increased with decreasing temperature, whereas the ratio of carboxylase to oxygenase activity was independent of temperature. This resulted in a disagreement between the measurements on the purified enzyme and intact leaf at low temperature. No disagreement between enzyme and leaf at low temperature occurred, when the ratio of photosynthesis to photorespiration was determined at increased $\mathrm{CO}_{2}$ concentrations.

The results suggest an effect of low temperature and low $\mathrm{CO}_{2}$ concentration on the ratio of photosynthesis to photorespiration independent of the enzyme.
\end{abstract}

Key words-Ribulose bisphosphate carboxylase oxygenase, photorespiration, temperature.

Correspondence to: Institut für Pflanzenbau, Eidgenössische Technische Hochschule, Universitätstrasse 2, CH-8092, Zürich, Switzerland.

\section{INTRODUCTION}

The temperature dependence of the ratio of photosynthesis to photorespiration has been attributed to the kinetic properties of ribulose bisphosphate carboxylase oxygenase (RuBPCO) (Laing, Ogren, and Hageman, 1974; Badger and Collatz, 1978) and to a change in the solubility ratio of $\mathrm{CO}_{2}$ to $\mathrm{O}_{2}(\mathrm{Ku}$ and Edwards, 1977a). The ratio of carboxylase to oxygenase of RuBPCO has been characterized by the $\mathrm{CO}_{2} / \mathrm{O}_{2}$ specificity factor $(S)$ (Laing et al., 1974; Jordan and Ogren, 1981):

$$
S=\frac{V_{\mathrm{c}} \cdot K_{\mathrm{o}}}{V_{\mathrm{o}} \cdot K_{\mathrm{c}}}=\frac{v_{\mathrm{c}} \cdot O}{v_{\mathrm{o}} \cdot C}
$$


where $V_{c}$ and $V_{\mathrm{o}}$ are maximal velocities of carboxylation and oxygenation, $v_{\mathrm{c}}$ and $v_{\mathrm{o}}$ are velocities of both reactions, $K_{\mathrm{c}}$ and $K_{\mathrm{o}}$ are Michaelis constants for $\mathrm{CO}_{2}$ and $\mathrm{O}_{2}$ respectively, and $O$ and $C$ are concentrations of $\mathrm{O}_{2}$ and $\mathrm{CO}_{2}$. The kinetic properties of RuBPCO are difficult to determine, but the methodology has improved in the last decade, since the requirement of $\mathrm{CO}_{2}$ and $\mathrm{Mg}^{++}$for activation of $\mathrm{RuBPCO}$ was recognized (Lorimer, Badger, and Andrews, 1977), and the ratio of carboxylase to oxygenase was measured in combined assays (Jordan and Ogren, 1981). However, there is still controversy as to whether the. temperature influence on the ratio of photosynthesis to photorespiration is due to RuBPCO kinetics (Hall and Keys, 1983; Jordan and Ogren, 1984).

The ratio is reflected in the $\mathrm{CO}_{2}$ compensation concentration $(\Gamma)$. Laing et al. (1974) related $\Gamma$ to the kinetic properties of RuBPCO by equation (2):

$$
S_{\text {in vivo }}=1 / 2 \cdot \frac{O}{\Gamma}
$$

where the factor $1 / 2$ is the proportion of $\mathrm{CO}_{2}$ released per $\mathrm{O}_{2}$ fixed. This enabled a direct comparison between gas exchange of leaves and kinetic properties of RuBPCO, whereby dark respiration was not considered. $\mathrm{Ku}$ and Edwards $(1977 \mathrm{~b})$ calculated kinetic constants of photosynthesis and its oxygen inhibition at various temperatures and compared the data with RuBPCO kinetics. However, no direct comparison of purified RuBPCO has yet been made with the ratios of photosynthesis to photorespiration determined from gas exchange at air level concentrations of $\mathrm{CO}_{2}$.

For that purpose the specificity factor in vivo can be determined from the differential uptake of ${ }^{14} \mathrm{CO}_{2}$ and ${ }^{12} \mathrm{CO}_{2}$ by leaves according to equation (3)

$$
S_{\text {in vivo }}=\frac{P}{2(P-F)} \cdot \frac{O}{C_{\mathrm{i}}}
$$

where $P$ is gross photosynthesis corrected for photorespired $\mathrm{CO}_{2}$ refixed due to gas phase resistance, $F$ is net photosynthesis, and $C_{\mathrm{i}}$ is $\mathrm{CO}_{2}$ concentration in the intercellular gas space. $P$ corresponds to the carboxylation rate $\left(v_{\mathrm{c}}\right)$ and $2(P-F)$ to the oxygenation rate $\left(v_{\mathrm{o}}\right)$. The present paper compares the effects of temperature on specificity factors in vitro and in vivo at air concentration of $\mathrm{CO}_{2}$ and increased $\mathrm{CO}_{2}$. The role of dark respiration, which is neglected in (3), is discussed.

\section{MATERIALS AND METHODS}

Plants of white clover (Trifolium repens $\mathrm{L}$., native ecotype) were propagated vegetatively and grown as described earlier (Schnyder, Mächler, and Nösberger, 1984). Day/night temperatures were $20^{\circ} \mathrm{C} / 16^{\circ} \mathrm{C}$ and irradiance was $400 \mu \mathrm{mol}$ quanta $\mathrm{m}^{-2} \mathrm{~s}^{-1}(400-700 \mathrm{~nm})$.

\section{Assays with purified RuBPCO}

Purification and activation: RuBPCO from young, newly unfolded white clover leaves was purified and freeze-dried as described by Mächler and Nösberger (1984). Protein was estimated according to Bensadoun and Weinstein (1976). To activate the enzyme used in separate assays, weighed amounts of the freeze-dried powder were dissolved in distilled water and an equal volume of $200 \mathrm{~mol} \mathrm{~m}^{-3} \mathrm{Tris}-\mathrm{HCl}$ (pH 8.4) containing $40 \mathrm{~mol} \mathrm{~m}^{-3} \mathrm{MgCl}_{2}$ and $10 \mathrm{~mol} \mathrm{~m}^{-3} \mathrm{NaHCO}_{3}$ was added. The mixture was heated at $50^{\circ} \mathrm{C}$ for $20 \mathrm{~min}$ and then kept at $0^{\circ} \mathrm{C}$. For combined assays, the freeze-dried enzyme was dissolved in $100 \mathrm{~mol} \mathrm{~m}{ }^{-3}$ Bicine ( $\mathrm{pH} 8 \cdot 2$ ), $20 \mathrm{~mol} \mathrm{~m} \mathrm{mgCl}_{2}, 5.0 \mathrm{~mol} \mathrm{~m}^{-3} \mathrm{NaHCO}_{3}$ and $10 \mathrm{~mol} \mathrm{~m}^{-3}$ orthophosphate, heated at $40^{\circ} \mathrm{C}$ for $30 \mathrm{~min}$ and then kept at $0^{\circ} \mathrm{C}$.

Separate assays: Procedures were based on the method of Lorimer et al. (1977). Carboxylase was tested in small test tubes and oxygenase in an oxygen electrode vessel (Hansatech Limited, King's Lynn, Norfolk, U.K.), both at the same temperatures and with the same buffers. One $\mathrm{cm}^{3}$ of test mixture contained $100 \mathrm{~mol} \mathrm{~m}^{-3}$ Tris- $\mathrm{HCl}, 20 \mathrm{~mol} \mathrm{~m}^{-3} \mathrm{MgCl}_{2}$ and $0.4 \mathrm{~mol} \mathrm{~m}^{-3}$ ribulose bisphosphate. The $\mathrm{pH}$ 
was adjusted to 8.23 at $20^{\circ} \mathrm{C}$ and $\mathrm{pH}$ changes due to temperature effects were taken into account. The buffer was freed of $\mathrm{CO}_{2}$ as described by Lorimer $e t$ al. (1977). For the carboxylase assay, $\mathrm{NaH}^{14} \mathrm{CO}_{3}$ was diluted in ' $\mathrm{CO}_{2}$-free' water and added to the mixture in various concentrations. The reaction was started by adding the enzyme (about $100 \mu \mathrm{g}$ protein). The mixture was stirred continuously. The reaction was stopped after $1 \mathrm{~min}$ by adding $0.1 \mathrm{~cm}^{3} 2 \mathrm{~N} \mathrm{HCl}$. An aliquot was transferred to a scintillation vial and dried at $60^{\circ} \mathrm{C}$ overnight. The acid stable activity was determined by liquid scintillation. For oxygenase assays, various concentrations of $\mathrm{O}_{2}$ were established in the oxygen electrode vessel by purging the buffer with gas mixtures of pure $\mathrm{N}_{2}$ and $\mathrm{O}_{2}$ using Wösthoff pumps (H. Wösthoff, Bochum, F.R.G.). The reaction was started by adding the enzyme solution which had been pre-equilibrated to the $\mathrm{O}_{2}$ partial pressure of the assay mixture. Oxygenase activity was calculated from the initial decrease of $\mathrm{O}_{2}$.

Combined assays were made in an oxygen electrode vessel according to the procedure of Hall and Keys (1983). The reaction buffer was ' $\mathrm{CO}_{2}$-free' and consisted of $100 \mathrm{~mol} \mathrm{~m}^{-3}$ Bicine and $20 \mathrm{~mol} \mathrm{~m}^{-3}$ $\mathrm{MgCl}_{2}$. The $\mathrm{pH}$ was adjusted to 8.21 at $20^{\circ} \mathrm{C}$ and $\mathrm{pH}$ changes due to temperature effects were taken into account. Different $\mathrm{O}_{2}$ concentrations were established by purging the medium with $\mathrm{O}_{2} / \mathrm{N}_{2}$ gas mixtures. $\mathrm{NaH}^{14} \mathrm{CO}_{3}\left(2.0 \mathrm{~mol} \mathrm{~m}^{-3}, 0.094 \mathrm{Ci} \mathrm{mol}^{-1}\right)$ and carbonic anhydrase $\left(50 \mathrm{U} \mathrm{cm}^{-3}\right)$ were added. Enzyme ( $100 \mu \mathrm{g}$ protein) was added and equilibrated for about $5 \mathrm{~min}$. The actual $\mathrm{O}_{2}$ partial pressures were $20,38,66$ and $99 \mathrm{kPa}$. The reaction was started by adding $0.4 \mathrm{~mol} \mathrm{~m}^{-3}$ ribulose bisphosphate which had been pre-equilibrated to the $\mathrm{O}_{2}$ concentration in the assay mixture. The combined test was stopped after 2 min by adding $0.1 \mathrm{~cm}^{3} 2 \mathrm{~N} \mathrm{HCl}$.

Oxygenase activity was determined from the $\mathrm{O}_{2}$ consumption during the assay period; carboxylase activity was estimated from the acid stable radioactivity in the assay mixture by liquid scintillation method.

Calculations: The $\mathrm{CO}_{2}$ concentrations in the solutions were calculated by the HendersonHasselbalch equation and $p \mathrm{~K}$ values were calculated using tables of Harned and Bonner (1945), assuming an ionic strength of 0.06 ( $p \mathrm{~K}$ values were $6.326,6.281,6.242,6.210$ and 6.184 at $10^{\circ} \mathrm{C}, 15^{\circ} \mathrm{C}$, $20^{\circ} \mathrm{C}, 25^{\circ} \mathrm{C}$ and $30^{\circ} \mathrm{C}$ respectively). The $\mathrm{O}_{2}$ concentrations in solutions were calculated using the solubility coefficients of standard tables (Lange's handbook of chemistry 1979). The slopes and intercepts of double reciprocal plots were determined according to the statistical method of Wilkinson (1961). The substrate specificity factor was calculated either from $K_{\mathrm{m}}$ and $V_{\max }$ values (separate assays) or from carboxylation and oxygenation rates in the combined assay.

\section{Gas exchange analysis with intact leaves}

Net photosynthesis and transpiration of attached white clover leaves were determined in an open gas exchange system using an IRGA (Binos, Leybold-Heraeus, Hanau, F.R.G.) and a dew point hygrometer (General Eastern, Watertown, Mass. U.S.A.). Air was mixed from gas cylinders using Wösthoff pumps and humidified by passing through washing flasks at $0-5^{\circ} \mathrm{C}$. The flow rate was $1.0 \mathrm{dm}^{3} \mathrm{~min}^{-1}$. Light was provided by a $34 \mathrm{~W}$ halogen mirror projection lamp (General Electric, Cleveland, Ohio, U.S.A.). Infrared radiation was reduced by a Calflex $C$ filter (Balzers, Balzers, Principality Liechtenstein) and a $2.5 \mathrm{~cm}$ water layer. A ball shaped flask containing water was located between the cuvette and the light source and provided for an equal distribution of the light on the leaf surface. The cuvette (volume $0.6 \mathrm{dm}^{3}$ ) was made of stainless steel, copper and plexiglass and contained a fan (Micronel Electronic, Tagelswangen, Switzerland). Air temperature in the cuvette was controlled by water circulating through the walls and the top of the cuvette. Leaf temperature was measured by a chromel-alumel thermocouple $(0.1 \mathrm{~mm})$ attached to the lower surface of the leaf. Leaf area was determined before IRGA measurements were made. Leaves were pre-adapted to experimental conditions for 30-45 min, before measurements of net photosynthesis and transpiration were taken.

${ }^{14} \mathrm{CO}_{2}$ uptake (gross photosynthesis) was measured after net photosynthesis. A cylinder $\left(4.0 \mathrm{dm}^{3}\right)$ containing compressed dry air and ${ }^{14} \mathrm{CO}_{2}$ was prepared as described by Ludwig and Canvin (1970). Ten $\mathrm{cm}^{3}$ air with a known amount of ${ }^{14} \mathrm{CO}_{2}$ was taken from the cylinder using a syringe and, after the system was closed, injected into the cuvette where it was rapidly distributed by the fan. After $20 \mathrm{~s}$ the bottom of the cuvette, where the stem of the leaf was held, was removed and the leaf was killed within 1-2 s by immersion in liquid $\mathrm{N}_{2}$ and then burnt in a carbon oxidizer (Packard Instruments Comp., Downers Grove, Ill. U.S.A.). The $\mathrm{CO}_{2}$ was absorbed in Carbosorb and after addition of Permafluor radioactivity was determined by liquid scintillation. The concentration of radioactivity in the cuvette at the beginning of exposure was determined in the absence of leaves: A sample of $10 \mathrm{~cm}^{3}$ air was removed from the cuvette, about $0.5 \mathrm{~cm}^{3}$ of inactive $\mathrm{CO}_{2}$ added, the $\mathrm{CO}_{2}$ absorbed in Carbosorb, Permafluor added and the radioactivity determined by liquid scintillation. The same content of radioactivity was 
found in samples of $10 \mathrm{~cm}^{3}$ air taken $1 \mathrm{~s}$ and $20 \mathrm{~s}$ after injection of ${ }^{14} \mathrm{CO}_{2}$ into the cuvette indicating rapid distribution. ${ }^{14} \mathrm{CO}_{2}$ uptake by leaves was linear for $30 \mathrm{~s}$ indicating that an exposure time of $20 \mathrm{~s}$ was sufficiently short and determinations not affected by respired ${ }^{14} \mathrm{CO}_{2}$.

Calculations: Net photosynthesis $(F)$ was calculated according to Čatský (1971). Stomatal conductance $\left(k_{\mathrm{g}}\right)$ was determined from transpiration measurements according to Jarvis (1971). Gross photosynthesis $(P)$ was calculated from ${ }^{14} \mathrm{CO}_{2}$ short time uptake. The application of a non-steady state system during ${ }^{14} \mathrm{CO}_{2}$ exposure brought about a slight deviation of the $\mathrm{CO}_{2}$ concentration from that during measurement of net photosynthesis and a decrease in specific radioactivity due to the evolution of ${ }^{12} \mathrm{CO}_{2}$ respired by the leaf. The change in $\mathrm{CO}_{2}$ concentration at the beginning of exposure due to the injection of $10 \mathrm{~cm}^{3}$ air containing ${ }^{14} \mathrm{CO}_{2}\left(103 \mathrm{~Pa} p\left(\mathrm{CO}_{2}\right)\right)$ into the cuvette $\left(600 \mathrm{~cm}^{3}\right)$ and its decrease during exposure (1-2 $\left.\mathrm{Pa} p\left(\mathrm{CO}_{2}\right)\right)$ due to photosynthesis were calculated. The decrease in specific radioactivity was calculated using estimates of ratios of photorespiration to net photosynthesis (0.0-0.3, depending on temperature and $\mathrm{CO}_{2}$ concentration). Gross photosynthesis was corrected for the deviation of the $\mathrm{CO}_{2}$ concentration in the closed system from the concentration in the open system by using $\mathrm{CO}_{2}$ concentration curves of photosynthesis. These corrections were made even though the effects were small and did not affect the significance of the results. Effects of temperature and barometric pressure on $\mathrm{CO}_{2}$ concentration were taken into account. ${ }^{14} \mathrm{CO}_{2}$ uptake was corrected for discrimination against ${ }^{14} \mathrm{CO}_{2}$ diffusion in the gas phase $\left(k_{12} / k_{14}=1.0088\right)$ and ${ }^{14} \mathrm{CO}_{2}$ carboxylation $\left(k_{12} / k_{14}=1.0568\right)$ (O'Leary, 1981). Intercellular concentrations of $\mathrm{CO}_{2}$ including respired $\mathrm{CO}_{2}\left(C_{\mathrm{i}}\right)$ and excluding respired $\mathrm{CO}_{2}\left({ }^{14} \mathrm{C}_{\mathrm{i}}\right)$ were calculated by applying Fick's first law according to equations (4a) and (4b)

$$
\begin{gathered}
C_{\mathrm{i}}=C_{\mathrm{a}}-F / k_{\mathrm{g}} \\
{ }^{14} C_{\mathrm{i}}=C_{\mathrm{a}}-\varphi / k_{\mathrm{g}}
\end{gathered}
$$

where $C_{\mathrm{a}}$ was $\mathrm{CO}_{2}$ concentration in the cuvette during measurement of net photosynthesis and $\varphi$ was ${ }^{14} \mathrm{CO}_{2}$ uptake. The underestimation of gross photosynthesis $(P)$ by the ${ }^{14} \mathrm{CO}_{2}$ uptake $(\varphi)$ due to refixation of respired ${ }^{12} \mathrm{CO}_{2}$ was corrected by equation (5)

$$
P=\frac{C_{\mathrm{i}}}{{ }^{14} C_{\mathrm{i}}} \cdot \varphi
$$

since the fixation rate of intercellular $\mathrm{CO}_{2}$ is independent of its origin (from ambient air $\left({ }^{14} C_{\mathrm{i}}\right)$ or from respiration $\left.\left(C_{\mathrm{i}}-{ }^{14} C_{\mathrm{i}}\right)\right)$.

The $\mathrm{CO}_{2} / \mathrm{O}_{2}$ specificity factor in vivo was calculated according to equation (3).

\section{RESULTS AND DISCUSSION}

The ratio of oxygenase to carboxylase in vitro and the ratio of photorespiration to photosynthesis in vivo were plotted against concentration ratios of dissolved $\mathrm{O}_{2}$ to $\mathrm{CO}_{2}$ in the assay medium or in the intercellular space of intact leaves, respectively (Figs 1, 2). Plots from in vitro experiments (Fig. 1) and from in vivo experiments at a light intensity of $2000 \mu \mathrm{mol}$ quanta $\mathrm{m}^{-2} \mathrm{~s}^{-1}$ (Fig. 2A) were straight lines passing through the origin of the axes. Straight lines were also obtained from in vivo experiments at $400 \mu$ mol quanta $\mathrm{m}^{-2} \mathrm{~s}^{-1}$ (Fig. 2B). However, they did not pass through the origin indicating interactions with dark respiration at this lower light intensity. Specificity factors are represented by the reciprocals of the slopes of the lines. No temperature response of the slopes was obtained from in vitro experiments (Fig. 1), whereas the slopes from in vivo experiments increased with temperature, independent of light intensity, implying a decrease in specificity factors (Fig. 2). This temperature effect was not due to a change in the solubility ratio of $\mathrm{O}_{2}$ to $\mathrm{CO}_{2}$ since concentrations of dissolved gases were plotted.

The temperature response of specificity factors in vitro was compared with specificity factors in vivo in Fig. 3. Both were of the same magnitude at high temperature. They diverged at low temperature. The specificity factors in vivo increased with decreasing temperature, whereas no temperature response was found in vitro, independent of the method of assay. It is not fully understood why a difference in size of specificity factors in vitro occurred in 


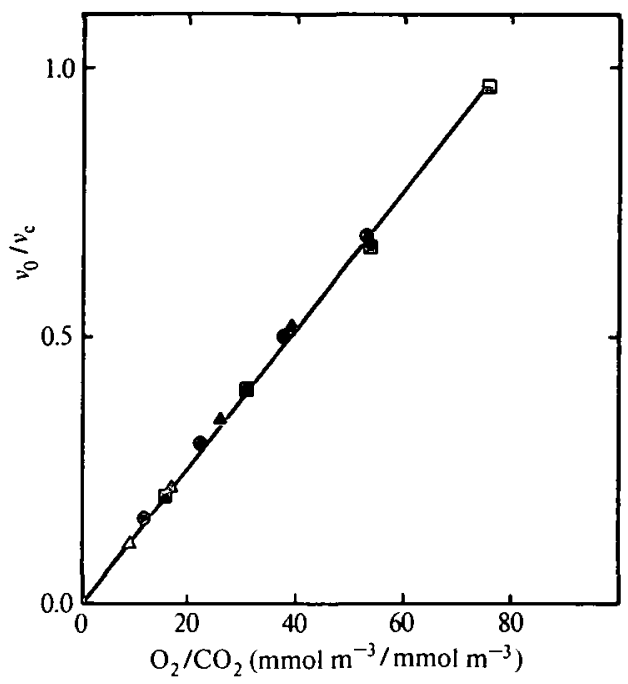

FIG. 1. The ratio of $v_{0}$ to $v_{c}$ of purified $\mathrm{RuBPCO}$ in relation to the ratio of dissolved $\mathrm{O}_{2}$ to $\mathrm{CO}_{2}$, determined in combined assays at $10^{\circ} \mathrm{C}(\square), 20^{\circ} \mathrm{C}(\bullet)$ and $30^{\circ} \mathrm{C}(\Delta) . \mathrm{NaHCO}_{3}$ concentration was kept constant $\left(2.0 \mathrm{~mol} \mathrm{~m}^{-3}\right)$ and $\mathrm{O}_{2}$ concentration was varied. The reciprocal of the slope represents the specificity factor in vitro. Means of two or three determinations are shown.
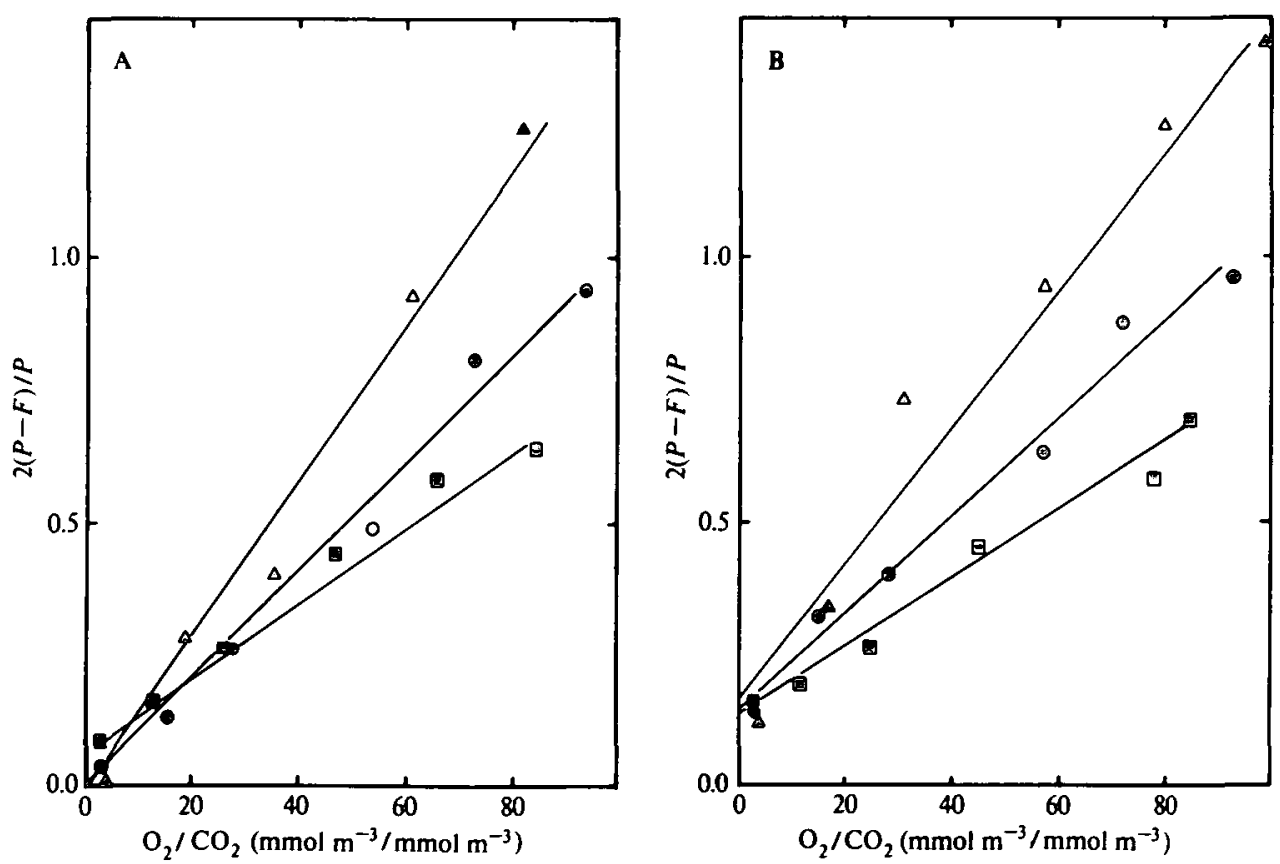

FIG. 2. The ratio of photorespiration to gross photosynthesis of leaves as a function of the ratio of dissolved $\mathrm{O}_{2}$ to $\mathrm{CO}_{2}$. Light intensity was $2000 \mu \mathrm{mol}$ quanta $\mathrm{m}^{-2} \mathrm{~s}^{-1}(\mathrm{~A})$ and $400 \mu \mathrm{mol}$ quanta m $\mathrm{m}^{-2} \mathrm{~s}^{-1}$ (B). Temperatures were $10^{\circ} \mathrm{C}($ (⿴囗口) $), 20^{\circ} \mathrm{C}(\odot)$ and $30^{\circ} \mathrm{C}(\Delta)$. Concentration of dissolved $\mathrm{CO}_{2}$ was in equilibrium with $30 \mathrm{~Pa} p\left(\mathrm{CO}_{2}\right)$ in the gas phase and $\mathrm{O}_{2}$ concentration was varied. The reciprocals of slopes represent the specificity factors in vivo. Means of two determinations are shown. 


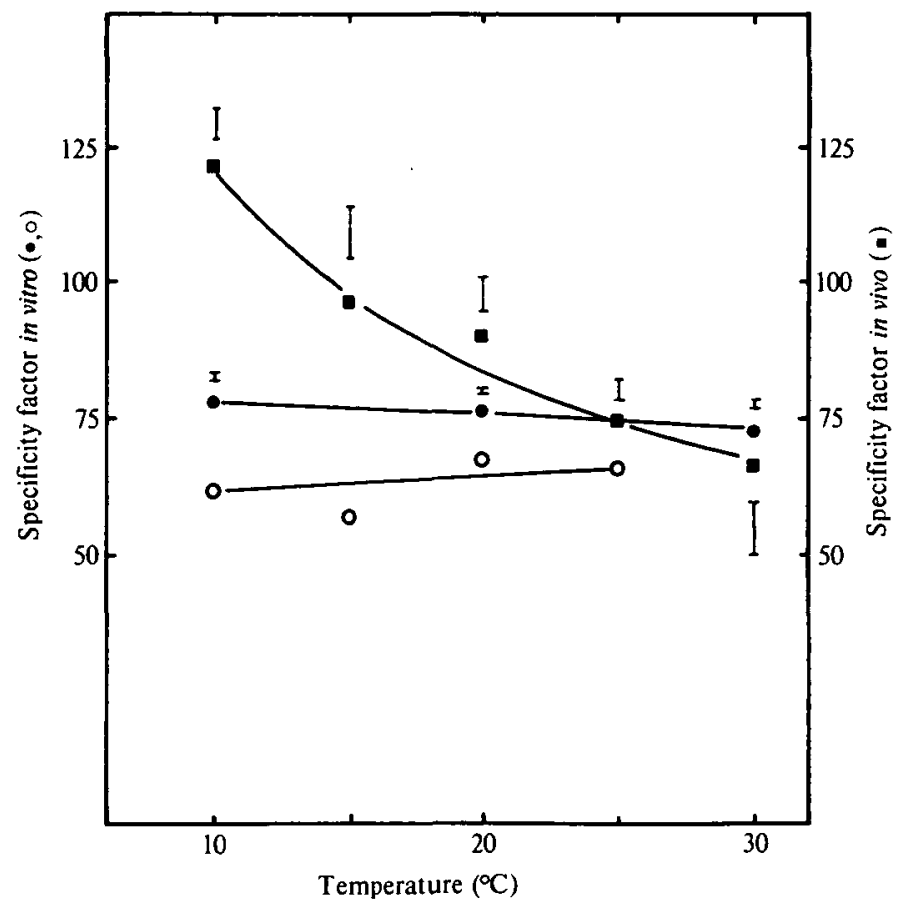

Fig. 3. Effect of temperature on the substrate specificity factors in vivo as calculated from gas exchange experiments at $30 \mathrm{~Pa} p\left(\mathrm{CO}_{2}\right)$ and $21 \mathrm{kPa} p\left(\mathrm{O}_{2}\right)(\square)$, and in vitro as calculated from combined $(\bullet)$ and separate (o) assays. Calculations of specificity factors are based on concentrations of dissolved gases. Means of two $(\square)$ or three ( $\bullet$ ) determinations are shown. Calculations from kinetic constants (0) are based on four determinations. Vertical bars indicate standard errors for combined assays and gas exchange experiments.

TA B LE 1. Effect of temperature on the kinetic constants of RuBPCO

$V_{\mathrm{o}}$ and $V_{\mathrm{c}}$ are maximal velocities of oxygenase and carboxylase, $K_{\mathrm{o}}$ and $K_{\mathrm{c}}$ are Michaelis constants for $\mathrm{O}_{2}$ and $\mathrm{CO}_{2}$. Means of seven to nine estimations (two replications at four or five substrate concentrations) are presented and standard errors are indicated in parenthesis.

\begin{tabular}{|c|c|c|c|c|}
\hline $\begin{array}{l}T \\
\left({ }^{\circ} \mathrm{C}\right)\end{array}$ & $\begin{array}{l}V_{0} \\
\left(\mu \mathrm{mol} \mathrm{O}_{2} \mathrm{~min}^{-1}\right. \\
\mathrm{mg}^{-1} \text { protein) }\end{array}$ & $\begin{array}{l}K_{\mathrm{o}} \\
\left(\mathrm{mmol} \mathrm{m} \mathrm{m}^{-3} \mathrm{O}_{2}\right)\end{array}$ & $\begin{array}{l}V_{\mathrm{c}} \\
\left(\mu \mathrm{mol} \mathrm{CO} \mathrm{Cmin}^{-1}\right. \\
\left.\mathrm{mg}^{-1} \text { protein }\right)\end{array}$ & $\begin{array}{l}K_{\mathrm{c}} \\
\left(\mathrm{mmol} \mathrm{m}{ }^{-3} \mathrm{CO}_{2}\right)\end{array}$ \\
\hline 10 & $\begin{array}{l}0.12 \\
(0.008)\end{array}$ & $\begin{array}{l}520 \\
(93 \cdot 3)\end{array}$ & $\begin{array}{l}0.10 \\
(0.003)\end{array}$ & $\begin{array}{l}7 \cdot 2 \\
(0.59)\end{array}$ \\
\hline 15 & $\begin{array}{l}0.15 \\
(0.003)\end{array}$ & $\begin{array}{l}521 \\
(26 \cdot 7)\end{array}$ & $\begin{array}{l}0.17 \\
(0.004)\end{array}$ & $\begin{array}{l}10.3 \\
(0.55)\end{array}$ \\
\hline 20 & $\begin{array}{l}0.21 \\
(0.017)\end{array}$ & $\begin{array}{l}598 \\
(104 \cdot 8)\end{array}$ & $\begin{array}{l}0.34 \\
(0.011)\end{array}$ & $\begin{array}{l}14 \cdot 2 \\
(1 \cdot 10)\end{array}$ \\
\hline 25 & $\begin{array}{l}0.27 \\
(0.023)\end{array}$ & $\begin{array}{l}619 \\
(104 \cdot 9)\end{array}$ & $\begin{array}{l}0-60 \\
(0.016)\end{array}$ & $\begin{array}{l}20 \cdot 8 \\
(1 \cdot 16)\end{array}$ \\
\hline
\end{tabular}

combined and separate assays. The independence of temperature of the specificity factor in vitro was characterized by an analysis of the kinetic constants (Table 1). The increase in the maximal velocity of the carboxylase reaction $\left(V_{c}\right)$ with temperature was compensated for by an increase in the maximal velocity of the oxygenase reaction $\left(V_{0}\right)$ and by an increase in the 
Michaelis constant for $\mathrm{CO}_{2}\left(K_{\mathrm{c}}\right)$, whereas the Michaelis constant for $\mathrm{O}_{2}\left(K_{\mathrm{o}}\right)$ was only slightly dependent on temperature.

The temperature response of the specificity factors in vivo, as calculated from ${ }^{14} \mathrm{CO}_{2}$ and ${ }^{12} \mathrm{CO}_{2}$ uptake at $30 \mathrm{~Pa} p\left(\mathrm{CO}_{2}\right)$, was consistent with calculations based on $\mathrm{CO}_{2}$ compensation concentrations (Jordan and Ogren, 1984). However, our finding that specificity factors in vitro were independent of temperature is in agreement only with some of the data as calculated from literature: independence of temperature, at least within a limited temperature range, could be shown when specificity factors were calculated from data by Badger and Collatz (1977) and Hall and Keys (1983). In contrast, Jordan and Ogren (1984) found an increase in specificity factors in vitro with decreasing temperature which agreed with our measurements of the temperature response in vivo.

The specificity factor in vivo at $30 \mathrm{~Pa} p\left(\mathrm{CO}_{2}\right)$ was low at $30^{\circ} \mathrm{C}$ and high at $10^{\circ} \mathrm{C}$ (Fig. 4). It was independent of $\mathrm{CO}_{2}$ at $30^{\circ} \mathrm{C}$, whereas at $10^{\circ} \mathrm{C}$ it decreased as $\mathrm{CO}_{2}$ concentration was increased. At $120-150 \mathrm{~Pa} p\left(\mathrm{CO}_{2}\right)$, it was similar at $30^{\circ} \mathrm{C}$ and at $10^{\circ} \mathrm{C}$. This $\mathrm{CO}_{2}$ response is consistent with calculations from data on ${ }^{14} \mathrm{CO}_{2} /{ }^{12} \mathrm{CO}_{2}$ uptake by Fock, Klug, and Canvin (1979).

The disagreement between specificity factors in vivo and in vitro at low temperature and at $\mathrm{a} \mathrm{CO}_{2}$ partial pressure of about $30 \mathrm{~Pa}$ or less, suggests that the temperature dependence of the ratio of photosynthesis to photorespiration is not fully explained by the properties of RuBPCO and by effects on the solubility ratio of $\mathrm{O}_{2}$ to $\mathrm{CO}_{2}$.

Disagreement between gas exchange and RuBPCO kinetics cannot be explained by effects of dark respiration. (1) If dark respiration, which is saturated at $2.0 \mathrm{kPa} p\left(\mathrm{O}_{2}\right)$ (Forrester,

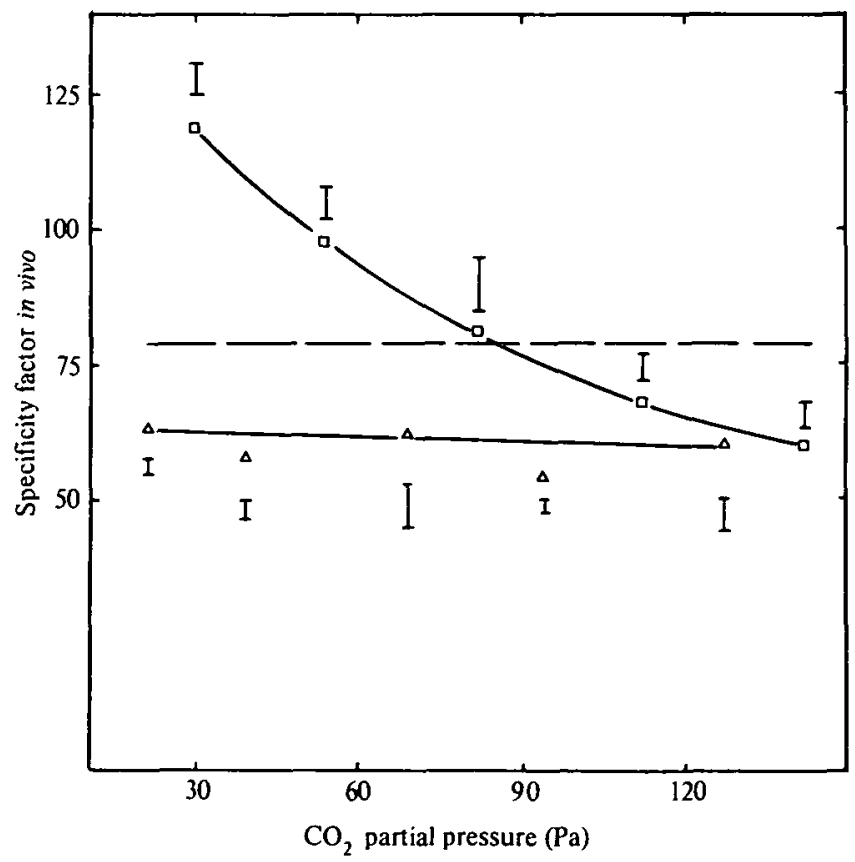

Fig. 4. Effect of intercellular $\mathrm{CO}_{2}$ partial pressure on the substrate specificity factor in vivo at $10^{\circ} \mathrm{C}$ (c) and $30^{\circ} \mathrm{C}(\Delta)$. The ratio of partial pressures of $\mathrm{CO}_{2}$ to $\mathrm{O}_{2}$ in the cuvette was held constant in the experiments $\left(15 \times 10^{-4}\right)$. Specificity factors were calculated using concentrations of dissolved $\mathrm{O}_{2}$ and $\mathrm{CO}_{2}$. The means of four or three determinations are shown; vertical bars indicate standard errors. The dashed line indicates the specificity factor in vitro at $10^{\circ} \mathrm{C}$ as calculated from combined assays. 
Krotkov, and Nelson, 1966), affected the data in Fig. 2A, then the lines would not pass through the origin. However, at $2000 \mu$ mol quanta $\mathrm{m}^{-2} \mathrm{~s}^{-1}$, the lines pass through the origin.

(2) Dark respiration would decrease the specificity factor in vivo as compared with in vitro. However, specificity factors in vivo tend to be higher than in vitro (Fig. 3). (3) The $\mathrm{CO}_{2}$ dependence of the specificity factor in Fig. 4 cannot be attributed to dark respiration, since, as far as we know, dark respiration is not affected by $\mathrm{CO}_{2}$.

$\mathrm{A} \mathrm{CO}_{2}$ concentrating system in the mesophyll cells could explain the discrepancy between gas exchange and RuBPCO kinetics. In the presence of a $\mathrm{CO}_{2}$ concentrating system, the $\mathrm{CO}_{2}$ concentration at the enzyme site would be increased and underestimated by the intercellular $\mathrm{CO}_{2}$ concentration. The calculation of the specificity factor in vivo according to equation (3) would result in an overestimation. Assuming saturation kinetics, a $\mathrm{CO}_{2}$ concentrating system is expected to be more efficient at low than at high $\mathrm{CO}_{2}$ concentrations. This appears to be consistent with the $\mathrm{CO}_{2}$ dependence of the specificity factor in vivo at low temperature in Fig. 4 which shows high specificity factors at low $\mathrm{CO}_{2}$ concentrations.

However, further research is needed to substantiate this hypothesis; namely the effect of refixation of respired $\mathrm{CO}_{2}$ due to intracellular resistances on the estimates of specificity factors in vivo should be elucidated.

\section{ACKNOWLEDGEMENTS}

The authors thank Mr Kiss and Mr Dörig for technical assistance, Ms Allenbach for growing the plants, and Ms Schoenberg for checking the English translation.

\section{LITERATURE CITED}

Badger, M. R., and Collatz, G. J., 1978. Studies on the kinetic mechanism of ribulose-1,5bisphosphate carboxylase and oxygenase reactions, with particular reference to the effect of temperature on kinetic parameters. Carnegie Institution of Washington, Yearbook, 77, 355-61.

Bensadoun, A., and Weinstein, D., 1976. Assay of proteins in the presence of interfering materials. Analytical Biochemistry, 70, 241-50.

CATSKÝ, J., 1971. General principles of using IRGA for measuring $\mathrm{CO}_{2}$ exchange rates. In Plant photosynthetic production. Manual of methods. Eds Z. Sesták, J. Catský and P. G. Jarvis. Dr. W. Junk, N.V. Publishers, The Hague. Pp. 162-6.

FocK, H., KLuG, K., and CANviN, D. T., 1979. Effect of carbon dioxide and temperature on photosynthetic $\mathrm{CO}_{2}$ uptake and photorespiratory $\mathrm{CO}_{2}$ evolution in sunflower leaves. Planta, 145, 219-23.

Forrester, M. L., Krotkov, G., and Nelson, C. D., 1966. Effect of oxygen on photosynthesis, photorespiration and respiration in detached leaves. I. Soybean. Plant Physiology, 41, 422-7.

Hall, N. P., and KeYS, A. J., 1983. Temperature dependence of the enzymic carboxylation and oxygenation of ribulose-1,5-bisphosphate in relation to effects of temperature on photosynthesis. Ibid. 72, 945-8.

HARNED, H. S., and BoNNER, F. T., 1945. The first ionisation of carbonic acid in aqueous solutions of sodium chloride. Journal of the American Chemical Society, 67, 1026-31.

JARVIS, P. G., 1971. The estimation of resistances to carbon dioxide transfer. In Plant photosynthetic production. Manual of methods. Eds Z. Sesták, J. Catský and P. G. Jarvis. Dr. W. Junk, N.V. Publishers, The Hague. Pp. 566-631.

JORDAN, D. B., and OGREN, W. L., 1981. A sensitive assay procedure for simultaneous determination of ribulose-1,5-bisphosphate carboxylase and oxygenase activities. Plant Physiology, 67, 237-45.

1984. The $\mathrm{CO}_{2} / \mathrm{O}_{2}$ specificity of ribulose-1,5-bisphosphate carboxylase/oxygenase. Dependence on ribulose bisphosphate concentration, $\mathrm{pH}$ and temperature. Planta, 161, 308-13.

Ku, S. B., and Edwards, G. E., 1977a. Oxygen inhibition of photosynthesis. I. Temperature dependence and relation to $\mathrm{O}_{2} / \mathrm{CO}_{2}$ solubility ratio. Plant Physiology, 59, 986-90.

$-1977 b$. Oxygen inhibition of photosynthesis. II. Kinetic characteristics as affected by temperature. Ibid. 59, 991-9.

LAING, W. A., OGREN, W. L., and HaGeman, R. H., 1974. Regulation of soybean net photosynthetic 
$\mathrm{CO}_{2}$ fixation by the interaction of $\mathrm{CO}_{2}, \mathrm{O}_{2}$ and ribulose-1,5-diphosphate carboxylase. Ibid. 54, 678-85.

LANGe, 1979. Handbook of chemistry. J. A. Dean (Ed.). McGraw-Hill Book Company, New York.

LORIMER, G. H., BADGER, M. R., and ANDREWS, T. J., 1977. D-Ribulose-1,5-bisphosphate carboxylase oxygenase. Improved methods for the activation and assay of catalytic activities. Analytical Biochemistry, 78, 66-75.

LudwiG, L. J., and CANviN, D. T., 1970. Gas-exchange system for simultaneous measurement of the $\mathrm{CO}_{2}$ and ${ }^{14} \mathrm{CO}_{2}$ fluxes from leaves. Canadian Journal of Botany, 49, 1299-1313.

MÄCHLER, F., and NÖSBERGER, J., 1984. Influence of inorganic phosphate on photosynthesis of wheat chloroplasts. II. RuBPCO activity. Journal of Experimental Botany, 35, 488-94.

O'Leary, M. H., 1981. Carbon isotope fractionation in plants, review. Phytochemistry, 20, 553-67.

SCHNYDER, H., MäCHLER, F., and NöSBERGER, J., 1984. Influence of temperature and $\mathrm{O}_{2}$ concentration on photosynthesis and light activation of RuBPCO in intact leaves of white clover. Journal of Experimental Botany, 35, 147-56.

WILKINSON, G. N., 1961. Statistical estimation in enzyme kinetics. Biochemical Journal, 80, 324-32. 